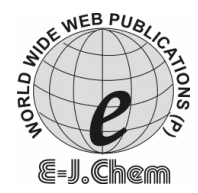

http://www.e-journals.net
ISSN: 0973-4945; CODEN ECJHAO

E-Journal of Chemistry 2010, 7(3), 1033-1039

\title{
An Assessment of the Quality of Groundwater in a Textile Dyeing Industrial Area in Erode City, Tamilnadu, India
}

\author{
P.N.PALANISAMY and S.K.KAVITHA* \\ Dept of Chemistry, Kongu Engineering College, \\ Perundurai, Erode, 638 052, Tamilnadu, India. \\ *Dept of Chemistry, Velalar College of Engg and Tech, \\ Erode - 638 012, Tamilnadu, India. \\ skkavitha@Yahoo.com
}

Received 9 December 2009; Accepted 5 February 2010

\begin{abstract}
Groundwater samples were collected in Erode city, Tamilnadu, from an area having large number of textile dyeing units. Though people residing in this area use river water supplied by local bodies as their major source for drinking, groundwater is also used as complementary source. The samples collected were subjected to systematic analysis using the standard methods and procedures. The values obtained for different physicochemical parameters were compared with the standard values given by ISI/ WHO. Variations in many physicochemical parameters were observed for most of the samples when compared to the standard values. More than half of the samples collected had their EC, TDS, total hardness, calcium, magnesium, sulphate and chloride exceeding their acceptable limits. This attempt has been made to determine the quality of groundwater in the study area confirms the deterioration of groundwater quality in the area and calls for some effective measures to be taken urgently to minimize the adverse impacts that may occur due to the contamination of groundwater.
\end{abstract}

Keywords: Groundwater, Textile dyeing, Erode, Industrial area.

\section{Introduction}

Water is the elixir for life. Adequate supply of potable safe water is absolutely essential and is the basic need for all human being on the earth. Due to rapid industrialization and subsequent contamination of surface and groundwater sources, water conservation and water quality management has now a days assumed a very complex shape $\mathrm{e}^{1,2}$. Attention on water contamination and its management has become a need of the hour because of its far reaching impact on human health. 
Erode, the headquarters of Erode district is a rapidly growing city and is one of the well known places for textile industries. It has more than 500 textile dyeing units. The dyeing units utilize large quantities of water for their process and generate wastewater containing considerable quantity of unused substances ${ }^{3,4}$.

The discharge of effluents having high TDS from dyeing industries results in the deterioration of the quality of groundwater to a greater extent ${ }^{5}$. Continuous disposal of industrial effluents on land, which has limited capacity to assimilate the pollution load also leads to groundwater pollution. Groundwater quality of open wells as well as deep bore wells deteriorates to a considerable extent and the water from such sources has high salt concentration ${ }^{6}$. To study the impact of the textile dyeing effluents on the quality of groundwater in Erode city, water samples were collected from some areas which have large number of textile dyeing units and the samples were analyzed for various physicochemical parameters.

\section{Experimental}

Sampling locations were selected based on detailed survey of the study area and discussions with local experts in waterworks department and Tamilnadu Pollution Control Board (TNPCB). Few locations away from industrialized area were also selected so as to make a comparative study on the quality of water. Samples were collected from open wells and bore wells. The depth of the wells varied from 30-60 meters. The details regarding the locations where samples were collected are given in Table 1.

Table 1. Details of the sampling location.

\begin{tabular}{ccl}
\hline Sample No. & Type of location & \multicolumn{1}{c}{ Location Place } \\
\hline $\mathrm{S}_{1}$ & OW & Sreenivasa nagar \\
$\mathrm{S}_{2}$ & OW & Appachi Ayya Thottam \\
$\mathrm{S}_{3}$ & BW & Perumal malai \\
$\mathrm{S}_{4}$ & OW & RN Pudur \\
$\mathrm{S}_{5}$ & OW & Amaravathi nagar \\
$\mathrm{S}_{6}$ & OW & Thanneer Pandal Palayam \\
$\mathrm{S}_{7}$ & BW & Kamaraj nagar \\
$\mathrm{S}_{8}$ & BW & Chinna Panankuttai \\
$\mathrm{S}_{9}$ & BW & Nanjappa nagar \\
$\mathrm{S}_{10}$ & BW & Vandipettai \\
$\mathrm{S}_{11}$ & BW & BP Agraharam \\
$\mathrm{S}_{12}$ & BW & Annai Sathya nagar \\
$\mathrm{S}_{13}$ & BW & Odaippallam \\
\hline \multicolumn{3}{c}{ OW - Open Well; $B W$ - Bore Well. }
\end{tabular}

\section{Sample collection}

Samples from thirteen locations were collected in clean polythene cans of one liter capacity. All the samples were collected during the month of October 2009. They were brought to the laboratory without the addition of any preservatives and subjected to physicochemical analysis within $24 \mathrm{~h}$ after the collection. Suspended matters if any, in the samples were removed by filtration through Whatman No.41.

\section{Analytical}

The samples collected were subjected to various physicochemical analysis in order to assess their quality and potability. Water samples were analyzed using standard methods ${ }^{7-9}$. 
The physical parameters studied were colour, odour, taste, turbidity, electrical conductivity and total dissolved solids. The chemical parameters studied were $\mathrm{pH}$, alkalinity, total hardness, $\mathrm{Ca}, \mathrm{Mg}$, iron, manganese, sodium, potassium, chloride, sulphate and fluoride. The $\mathrm{pH}$ values of the samples were determined using $\mathrm{pH}$ electrode 9107 and an expandable ion analyzer EA940. Electrical conductivity was measured using Elico CM-180 conductivity meter. Sulphate was determined by turbidimetric method. Total hardness, alkalinity, chloride and other constituents were estimated by using standard methods for water and wastewater ${ }^{8,9}$.

\section{Results and Discussion}

The values obtained for various physicochemical parameters after the analytical study are given in Table 3. The values were compared with the standard values given by $\mathrm{WHO}^{10}$ and ISI $^{11}$ given in Table 2.

Table 2. Standard values for Potability.

\begin{tabular}{ccc}
\hline S. No. & Parameter & Standard Value \\
\hline 1 & pH & $7-8.5$ \\
2 & EC & $300 \mu \mathrm{S}$ \\
3 & TDS & 500 \\
4 & Chloride & 200 \\
5 & Sulphate & 400 \\
6 & Total Hardness & 600 \\
7 & DO & 5.0 \\
8 & Ca & 100 \\
9 & $\mathrm{Mg}$ & 30 \\
10 & Fe & 0.5 \\
11 & Fluoride & 0.1 \\
\hline
\end{tabular}

(All values in ppm except S.No. 1 and 2).

Table 3. The values obtained for various physicochemical parameters in the study area.

\begin{tabular}{cccccccccccccc}
\hline & $\mathrm{S}_{1}$ & $\mathrm{~S}_{2}$ & $\mathrm{~S}_{3}$ & $\mathrm{~S}_{4}$ & $\mathrm{~S}_{5}$ & $\mathrm{~S}_{6}$ & $\mathrm{~S}_{7}$ & $\mathrm{~S}_{8}$ & $\mathrm{~S}_{9}$ & $\mathrm{~S}_{10}$ & $\mathrm{~S}_{11}$ & $\mathrm{~S}_{12}$ & $\mathrm{~S}_{13}$ \\
\hline $\mathrm{pH}$ & 7.34 & 7.75 & 7.5 & 7.7 & 7.46 & 7.52 & 7.43 & 7.11 & 7.73 & 7.13 & 7.22 & 7.23 & 7.25 \\
$\mathrm{EC}$ & 198 & 479 & 306 & 870 & 559 & 1625 & 1879 & 2653 & 242 & 3172 & 2660 & 1434 & 1706 \\
$\mathrm{Cl}^{-}$ & 57 & 50 & 177 & 248 & 213 & 879 & 794 & 1368 & 142 & 1588 & 1383 & 475 & 801 \\
$\mathrm{TDS}^{2-}$ & 294 & 251 & 665 & 937 & 712 & 1944 & 2036 & 2858 & 764 & 3256 & 2900 & 1500 & 2202 \\
$\mathrm{SO}_{4}{ }^{-}$ & 18 & 17 & 46 & 92 & 74 & 181 & 327 & 311 & 46 & 402 & 181 & 130 & 192 \\
$\mathrm{TH}$ & 137 & 119 & 150 & 285 & 216 & 718 & 731 & 1025 & 181 & 1230 & 1076 & 480 & 867 \\
$\mathrm{DO}$ & 4.2 & 3.3 & 4.2 & 4.3 & 3.8 & 4.1 & 3.7 & 3.2 & 4.5 & 5.1 & 3.1 & 4.4 & 3.8 \\
$\mathrm{Ca}$ & 34.2 & 29.8 & 37.5 & 71.2 & 54.0 & 179.5 & 182.8 & 256.2 & 45.2 & 307.5 & 269 & 120.1 & 216.7 \\
$\mathrm{Mg}$ & 12.4 & 10.8 & 13.6 & 25.9 & 19.6 & 65.3 & 66.4 & 93.2 & 16.4 & 118.8 & 97.8 & 43.6 & 78.8 \\
$\mathrm{Fe}$ & 0 & 0 & 0 & 0 & 0 & 0 & 0 & 0 & 0 & 0.3 & 0.2 & 0 & 0.1 \\
$\mathrm{~F}$ & 0.2 & 0.2 & 0.4 & 0.6 & 0.3 & 0.6 & 0.6 & 0.6 & 0.3 & 0.6 & 0.4 & 0.5 & 0.6 \\
$\mathrm{Na}$ & 161 & 115 & 122 & 287 & 214 & 165 & 232 & 326 & 316 & 238 & 362 & 261 & 327 \\
$\mathrm{~K}$ & 31 & 6 & 57 & 16 & 23 & 32 & 8 & 65 & 61 & 46 & 19 & 22 & 18 \\
\hline
\end{tabular}

(All values in ppm except $p H$ and $E C$ ).

All the 13 samples analyzed were not having any objectionable colour, appearance, taste or odour. All the samples had their $\mathrm{pH}$ values between 7 to 8 and these were well within the permissible limit of 6.5 to 8.5 prescribed for drinking water by Indian standards ${ }^{11}$. 
Maximum $\mathrm{pH}$ of 7.8 was observed for sample $\mathrm{S}_{10}$ collected from Vandipettai and minimum of 7.1 was observed for sample $S_{8}$ collected from Chinnapananguttai. Among the physical parameters analyzed, variations were observed for most of the samples regarding their electrical conductivity and total dissolved solids. The samples analyzed were found to have electrical conductivity values varying between $198-3172 \mu \mathrm{S} / \mathrm{cm}$. The EC values of six samples $S_{6}, S_{7}, S_{8}, S_{10}, S_{11}$ and $S_{13}$ collected from Thanneerpandal Palayam, Kamaraj Nagar, Chinnapananguttai, Vandipettai, BP Agraharam and Odaipallam were found to exceed the permissible limit of EC for drinking water $(300 \mu \mathrm{S} / \mathrm{cm})$ as per the ISI standards ${ }^{11,12}$. Maximum value of EC was found in sample $S_{10}$ collected from Vandipettai, while the minimum value of EC was observed in sample $S_{1}$ collected from Srinivasa Nagar. The EC variations in the samples analyzed is shown in Figure 1. The electrical conductivity value is an index to represent the total concentration of soluble salts in water ${ }^{13}$. This is confirmed by the fact that these samples were found to have fairly high values of TDS also. It is observed that waters with high EC values are predominant in sodium and chloride ions ${ }^{14}$. When the concentrations of both the ions were considered together, all the samples with high electrical conductivity were found to have both the ions at higher concentration.

The TDS concentration of the samples analyzed varied between $251 \mathrm{mg} / \mathrm{L}$ to $3256 \mathrm{mg} / \mathrm{L}$. All the samples except $S_{1}$ and $S_{2}$ had their TDS values above the standards prescribed. The higher value of TDS could be due to the low water levels within the aquifers and sediment effect ${ }^{15}$. The sample $S_{10}$ collected from Vandipettai had the highest TDS value of $3256 \mathrm{mg} / \mathrm{L}$ while the sample $S_{2}$ collected from Appachi Ayya Thottam had the minimum TDS value of $251 \mathrm{mg} / \mathrm{L}$. The trend of TDS variations is shown in Figure 2.

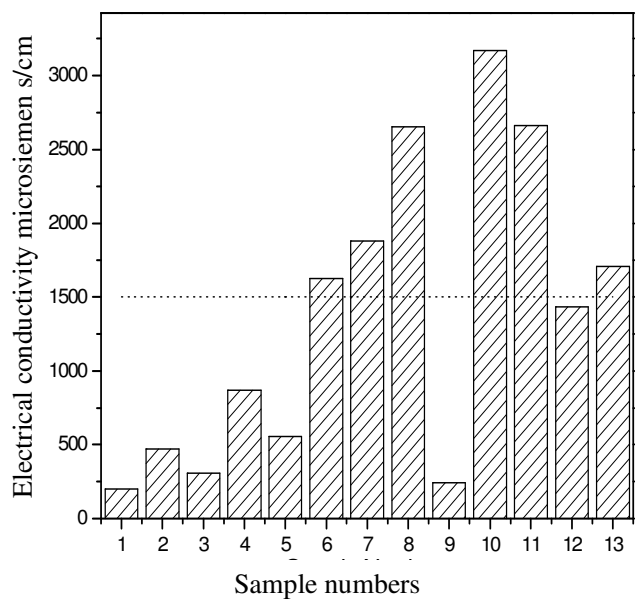

Figure 1. Electrical conductivity in the water samples (Dotted line indicates the permissible limit).

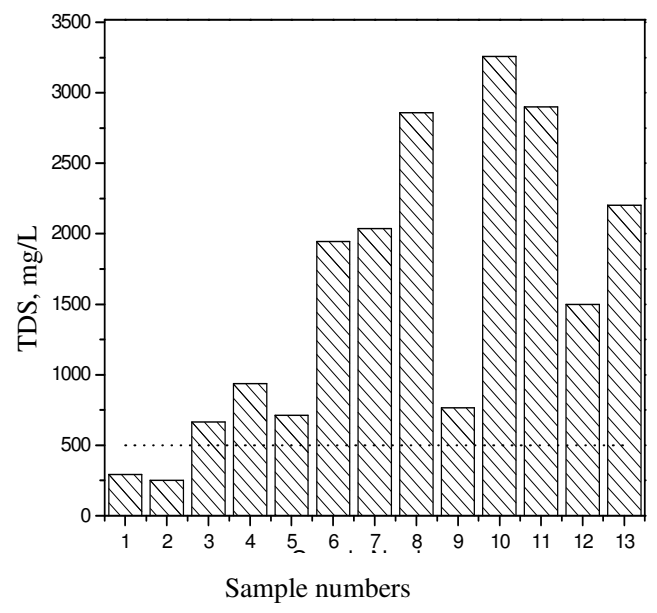

Figure 2. TDS in the water samples (Dotted line indicates the permissible limit).

The samples $\mathrm{S}_{6}-\mathrm{S}_{13}$ were collected from locations where textile dyeing industries are located in large number. The effluents from the dyeing units in the study area ultimately reach Kalingarayan canal, a $91 \mathrm{~km}$ long canal originating from Cauvery River and meant for the purpose of irrigation. The subsequent percolation of effluent water into the groundwater system in the downstream aquifers may be the reason for the alarmingly high TDS values of groundwater samples collected from these areas. The TDS values of only two samples $S_{1}$ and $S_{2}$ collected from Sreenivasa Nagar and Appachi Ayya Thottam 
which are in the upstream area were within the acceptable limit. These two locations do not have dyeing units also. This also confirms the fact that the percolation of effluents from textile dyeing units into the groundwater systems may also be the reason for the very high TDS values observed for the samples collected from other locations which are having many dyeing units.

Most of the samples analyzed showed higher concentration of chloride than the permissible limit prescribed for drinking water. The concentration of chloride ranged from a minimum of $50 \mathrm{mg} / \mathrm{L}$ for the sample $S_{2}$ collected from Appachi Ayya Thottam to a maximum of $1588 \mathrm{mg} / \mathrm{L}$ for the sample $S_{10}$ collected from Vandipettai. All the samples, except four samples $S_{1}, S_{2}, S_{3}$ and $S_{9}$, had their chloride concentrations above the permissible limit $(200 \mathrm{mg} / \mathrm{L})$. It was found to be within the acceptable limit of $500 \mathrm{mg} / \mathrm{L}$ for the samples $S_{4}, S_{5}$ and $S_{12}$. The other six samples had their chloride concentration exceeding the acceptable limit. The variation in chloride concentration is shown in Figure 3. The level of sulphate in the samples ranged from $18 \mathrm{mg} / \mathrm{L}$ to $402 \mathrm{mg} / \mathrm{L}$. It was well within the acceptable limit for all the samples except for the samples $S_{7}$ and $S_{10}$ and even in case of those two samples the variation was very less only.

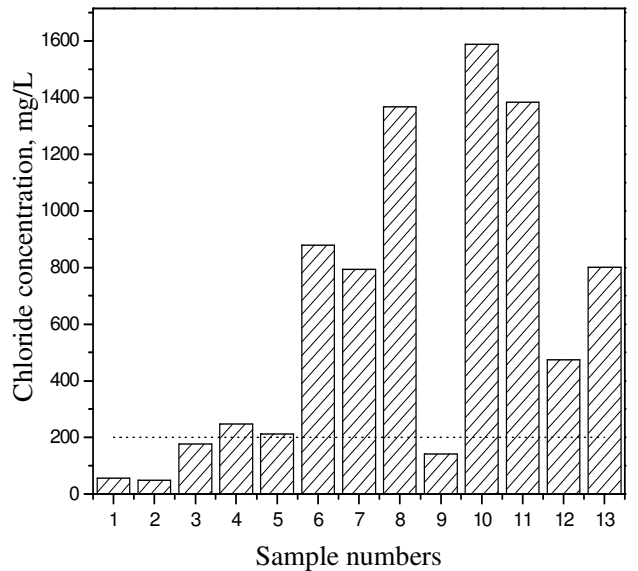

Figure 3. Chloride concentration in the water samples (Dotted line indicates the permissible limit).

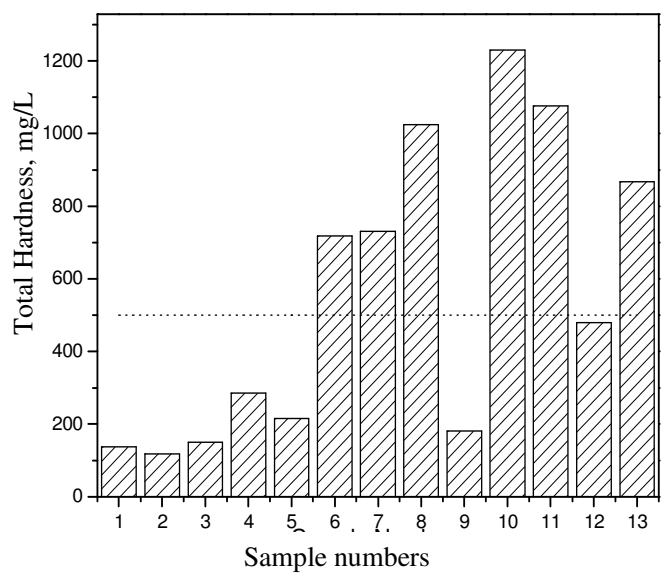

Figure 4. Total Hardness in the water samples (Dotted line indicates the permissible limit).

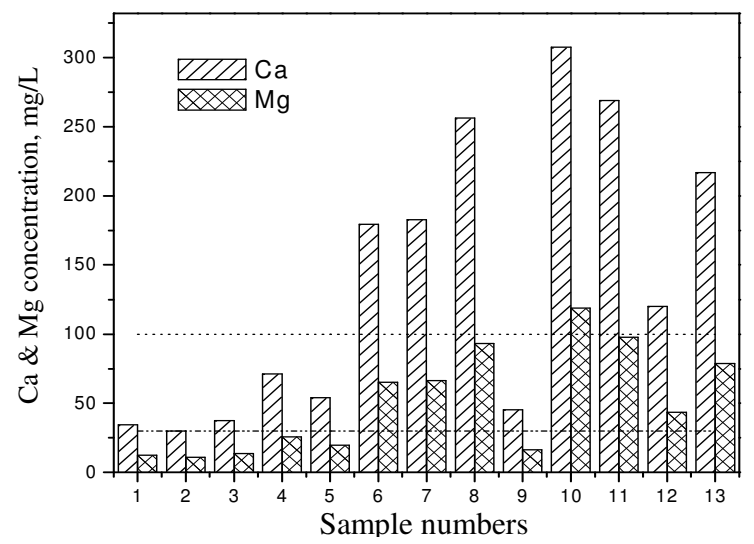

Figure 5. $\mathrm{Ca} \& \mathrm{Mg}$ concentration in the water samples (Dotted line indicates the permissible limit). 
The total hardness of the samples ranged from $137 \mathrm{mg} / \mathrm{L}$ to $1230 \mathrm{mg} / \mathrm{L}$. Six samples $\mathrm{S}_{6}, \mathrm{~S}_{7}$, $\mathrm{S}_{8}, \mathrm{~S}_{10}, \mathrm{~S}_{11}$ and $\mathrm{S}_{13}$ had their total hardness above the acceptable limit of $500 \mathrm{mg} / \mathrm{L}$. It was found to be the highest again in case of the sample $S_{10}$. The concentrations of calcium and magnesium also exceeded the acceptable limit for the samples $S_{6}, S_{7}, S_{8}, S_{10}, S_{11} S_{12}$ and $S_{13}$. The variations in the total hardness and the concentration of calcium and magnesium for the samples analyzed are shown in Figure $4 \& 5$ respectively. The concentration of sodium and potassium were found comparable with the earlier reported values ${ }^{16}$. Other chemical parameters like alkalinity, fluoride, sodium and potassium were well within the permissible limits.

\section{Conclusion}

Among the thirteen samples analyzed, only two samples $S_{1}$ and $S_{2}$ have good potability with no physicochemical parameters exceeding the permissible limit. Though the samples $S_{3}, S_{4}$, $\mathrm{S}_{5}$ and $\mathrm{S}_{9}$ have some of the parameters exceeding their limits the variations are only less and hence they are also potable.

Seven of the samples $S_{6}, S_{7}, S_{8}, S_{10}, S_{11} S_{12}$ and $S_{13}$ which were collected from locations where the number of textile dyeing units are more, have all the common chemical parameters like TDS, hardness etc alarmingly above the acceptable limits. The consumption of water having high total dissolved solids and hardness may cause harmful effects like kidney stone formation and other related diseases ${ }^{14}$. Though the sources from which the water samples were collected are used mainly as complementary sources of drinking water, the usage of water from these sources should be totally discouraged. Groundwater sources in the study area are used also for the processing of textile dyeing and bleaching operations by the industries located in the area. Even though the dyeing and bleaching industries discharge wastewater with higher salt concentration, they need water of very good quality for their processing. Therefore the groundwater with higher total hardness and TDS in the study area may become unsuitable for industrial applications also, if the contamination continues to proceed. Hence some effective measures are to be taken urgently to prevent the contamination of groundwater in the study area.

\section{References}

1. Sinha D K and Ritesh Saxena, J Environ Sci Engg., 2006, 48(3), 157.

2. Palanisamy P N, Geetha A, Sujatha M, Sivakumar P and Karunakaran K, E Journal of Chemistry, 2007, 4(3), 434.

3. Ibrahim Bathusha M and Saseetharan M K, Indian J Environ Protect., 2006, 26(6), 508.

4. Geetha A and Palanisamy P N, Sivakumar P, Ganesh Kumar P and Shujatha M, E Journal of Chemistry, 2008, 5(4), 696.

5. Kalaivani D, Banumathi V and Kasthuri R, Indian J Environ Protect., 2007, 27(11), 1011.

6. Manzoor S, Munir Shah H, Shaheen N and Khalique A, J Hazard Mat., 2006, 137(11), 3 .

7. APHA, Standard Methods for Examination of Water and Wastewater, Washington,D.C. $18^{\text {th }}$ Ed, 1992.

8. Manivasakam N, Physicochemical Examination of Water and Sewage and Industrial effluents $3^{\text {rd }}$ Ed.,Pragati Prakashan, Meerut, India, 1996.

9. Kotaiah B and Kumarasamy N, Environmental Engineering Laboratory Manual, $1^{\text {st }}$ Ed., Charotar Publishing House Pvt.Ltd., India. 
10 HO, International Standards for Drinking Water, World Health Organization, Geneva, 1971.

11. ISI Indian Standard Specification for drinking water, IS:10500, 1983

12. Ramaniah S V, Venkata Mohan S, Rajkumar B and Sarma. P N, J Environ Sci Engg., 2006, 48(2), 129.

13. Purandara B K, Varadarajan N and Jayashree K, Pollut Res., 2003, 22(2), 189.

14. Freeda Gnana Rani D, J Environ Sci Engg., 2003, 48(3), 199.

15. Damodaram T and Suresh S, Pollut Res., 2005, 24(1), 239.

16. Sunitha V, Sudarshan V and Rajeswara Reddy B, Pollut Res., 2005, 24(1), 217. 


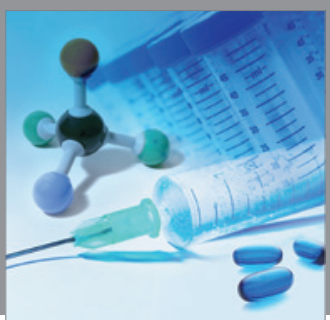

International Journal of

Medicinal Chemistry

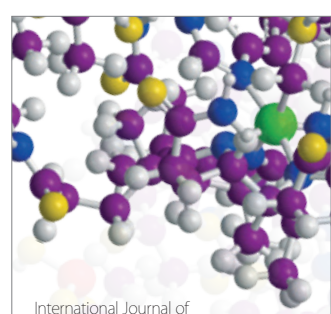

Carbohydrate Chemistry

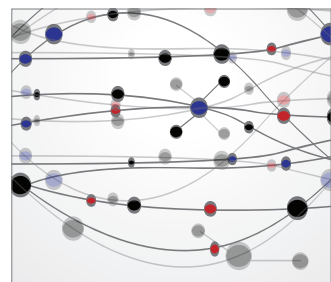

The Scientific World Journal
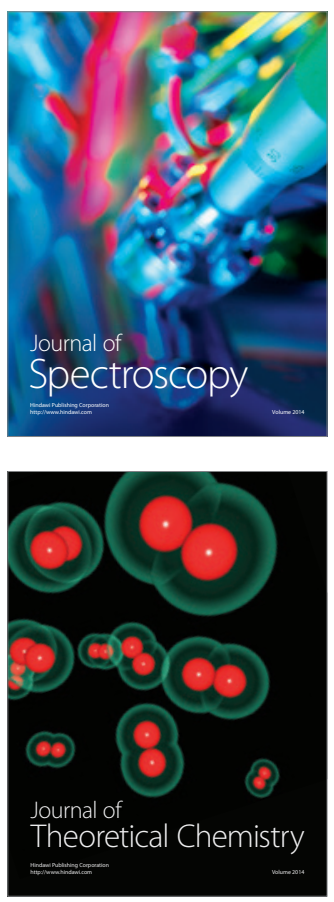
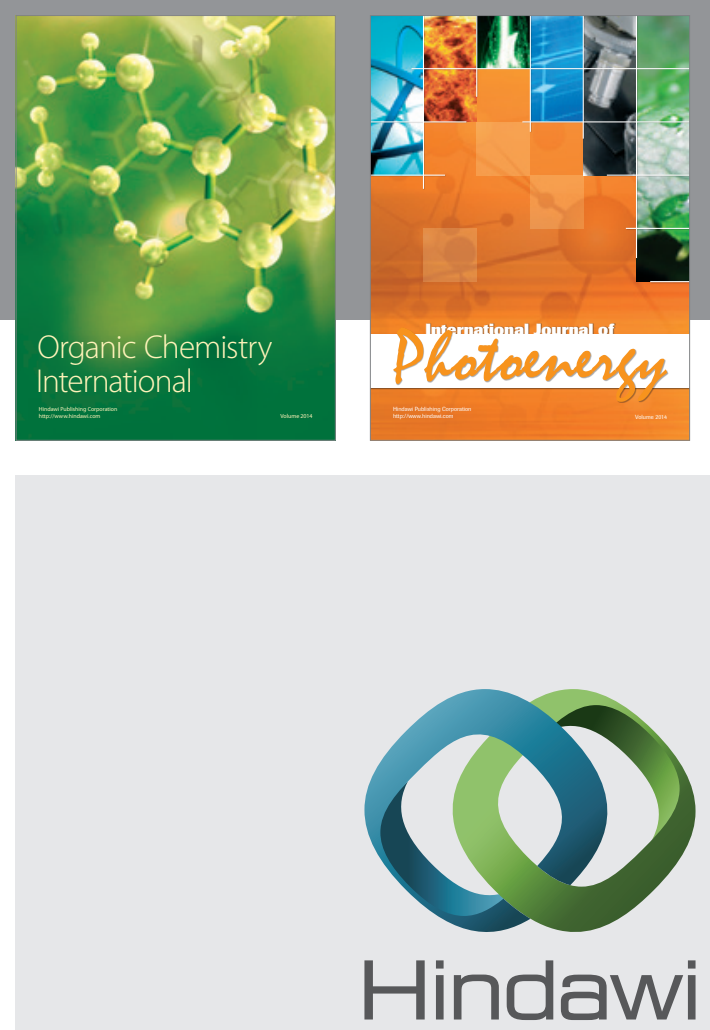

Submit your manuscripts at

http://www.hindawi.com
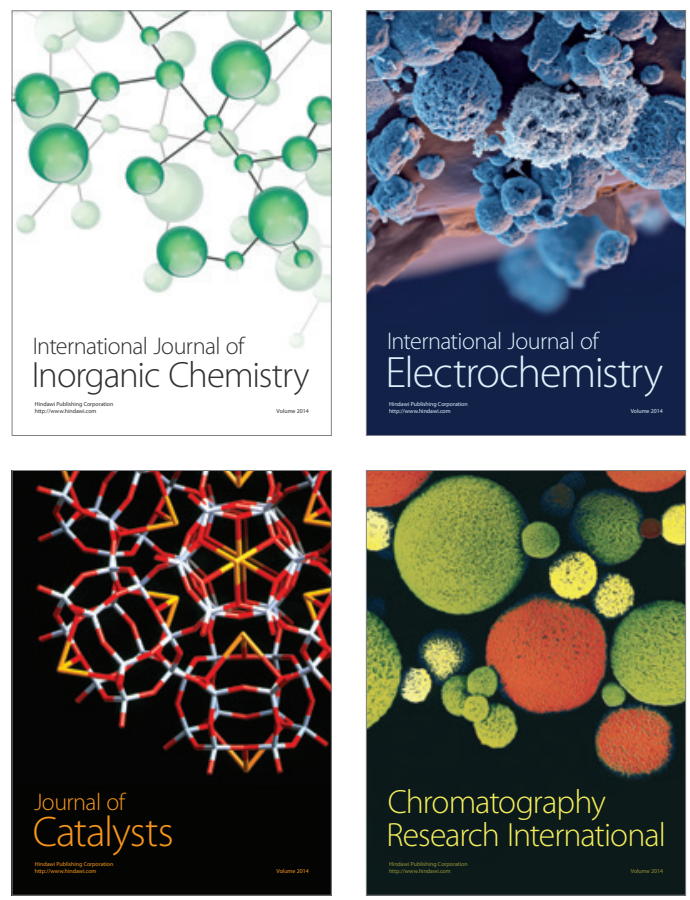
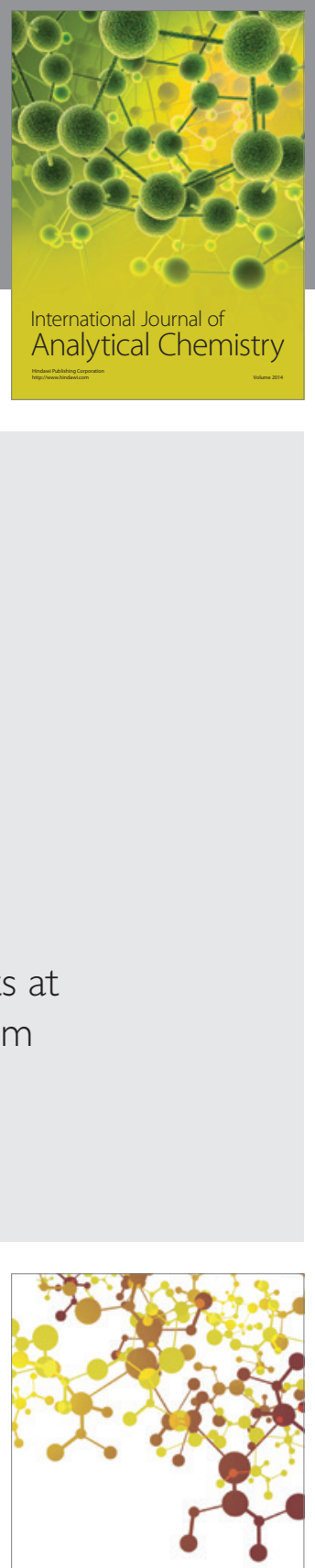

Journal of

Applied Chemistry
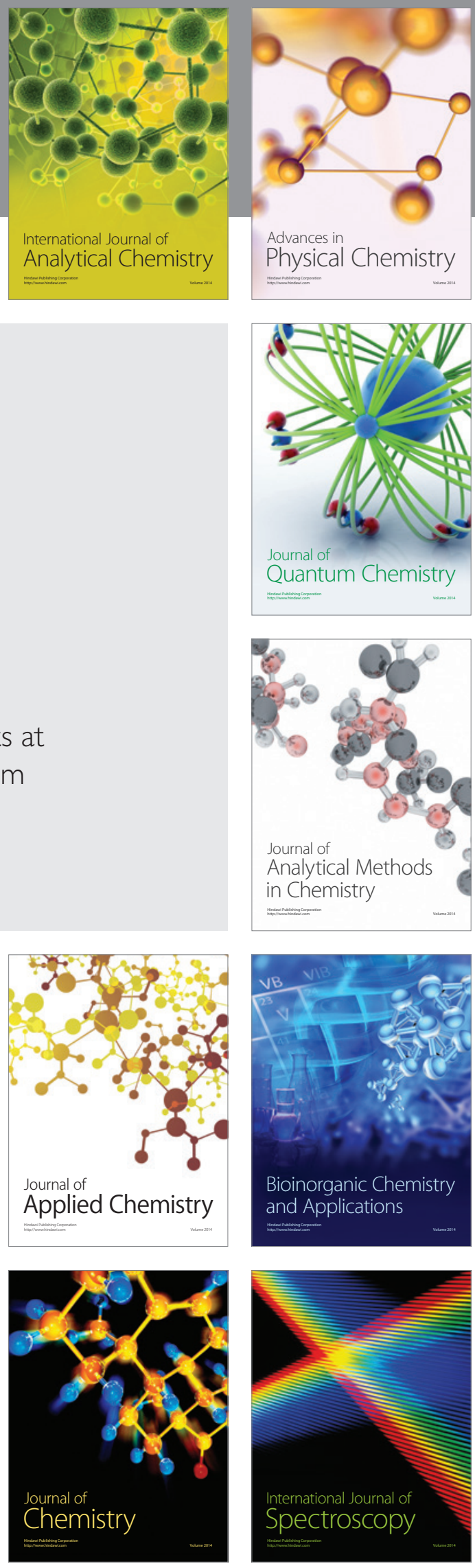